\title{
COLUNA/COLUMNA
}

\section{Por que Diretrizes Clínicas baseadas em eVIdência?}

Q ualquer lugar, grupo ou pessoa envolvida com a assistência médica deve estar preparado para responder a ao menos quatro questões: "O que eu faço em minha prática clínica?", "Para quem eu faço?", "Como eu faço?", "Por que eu faço?".

A possibilidade e a capacidade de responder a essas questões podem ser definidas como o testemunho da prática clínica e configuram como uma marca de qualidade de assistência à saúde.

A elaboração e a utilização das Diretrizes Clínicas podem ser interpretadas como uma forma de cercear ou limitar a prática, quando, na verdade, trata-se de escrever e tornar explícito o testemunho de nossas ações em Saúde no Brasil, fornecendo claramente a força das evidências científicas que sustenta cada uma dessas ações.

Testemunhar através de Diretrizes Clínicas baseadas em evidência é recomendar estimando o nível de incerteza envolvido na tomada de decisão.

As recomendações em Ortopedia, sobretudo em coluna, também podem e devem seguir essa visão: as Diretrizes Clínicas baseadas em evidência estabelecem padrões com opções de conduta centradas no paciente, que nada mais é do que a testemunha: 1 . O que fazemos: ações relevantes e indispensáveis em diagnóstico, prevenção, terapêutica e prognóstico que vêm sendo tomadas nas diversas situações clínicas que enfrentamos na prática; 2 . Para quem fazemos: para os pacientes-alvo do benefício, atendendo às suas expectativas e individualidade, sem esquecer as minorias; 3. Como fazemos: o detalhamento de como as ações são desenvolvidas, estabelecendo o link claro com a evidência disponível e apropriada para cada ação; 4 . Por que fazemos: quais os benefícios e riscos envolvidos nas atitudes médicas que as justifiquem.
Por meio das Diretrizes Clínicas podemos confrontar nossa prática com as recomendações, o que permite não só nos educarmos e atualizarmos, mas também refletirmos sobre a principal questão: qual o nível de incerteza que estou assumindo frente ao meu paciente com minha prática atual?

As Sociedades de Especialidades Médicas, incluindo a Sociedade Brasileira de Ortopedia e Traumatologia (SBOT), têm assumido o papel de testemunhar. Sabemos das dificuldades em se lidar com a obtenção e a crítica da evidência. Sabemos das pressões de interesses descentrados dos pacientes. Sabemos das dificuldades do Sistema de Saúde Nacional relacionadas à estrutura, pluralidade e inequidade. Mas também sabemos do esforço e determinação de muitos para, por meio das Diretrizes, estabelecerem uma linguagem reflexiva, ética, baseada em evidência, flexível e que atenda às necessidades fundamentais e expectativas dos pacientes.

Wanderley Marques Bernardo Coordenador do Núcleo SaBEReS

(Saúde Baseada em Evidência e Revisão Sistemática)

Universidade de São Paulo - USP, São Paulo (SP), Brasil 